INTERNATIONAL JOURNAL OF PLANT PROTECTION VOLUME 9 | ISSUE 2 | OCTOBER, 2016 | 387-394
- e ISSN-0976-6855 | Visit us : www.researchjournal.co.in

\title{
Screening of germplasm for tolerrance against major stem pests of soybean
}

\author{
A.A. MOTAPHALE*, B.B. BHOSLE AND F.S. KHAN
}

Department of Entomology, College of Agriculture, Vasantrao Naik Marathwada Krishi Vidyapeeth, PARBHANI (M.S.) INDIA

\section{ARITCLE INFO}

Received : 09.05 .2016

Revised : 04.08 .2016

Accepted : 18.08 .2016

\section{KEY WORDS :}

Germplasm, Stem pests,

Soybean

\section{ABSTRACT}

Field experiments were conducted during Kharif 2010-2011 and 2011-12, at the field of College of Agriculture, Marathwada Krishi Vidyapeeth, Parbhani (Maharashtra). Twenty two germplasm were screened for tolerance against major insect pests of soybean. During 2010 Genotypes DSb 16 (2199.1 kg/ha) with the highest yield under unprotected conditions was considered as tolerant check. Among the entries tested, two entries viz., SL-799, DSb-16 and three checks JS 93-05, JS-335 and MAUS-158 were categorized as high yielding entries. During 2011, the per cent yield loss in different genotypes ranged from 14.35 (PS 1466) to 61.56 (JS 97-52). Under protected and unprotected conditions yield obtained from JS 93-05 $(1621.31 \mathrm{~kg} / \mathrm{ha})$ to DS $12-13$ $(2526.61 \mathrm{~kg} / \mathrm{ha})$ and from PS $1466(1089.65 \mathrm{~kg} / \mathrm{ha})$ to DSb $16(2199.06 \mathrm{~kg} / \mathrm{ha})$. Among the entries PS-1466 categorized as resistant high yielding entry.

How to view point the article : Motaphale, A.A., Bhosle, B.B. and Khan, F.S. (2016). Screening of germplasm for tolerrance against major stem pests of soybean. Internat. J. Plant Protec., 9(2) : 387-394, DOI : 10.15740/HAS/IJPP/9.2/387-394. 